\title{
Effects of Complex Price Communication on Fairness: Case of a Sequential Communication
}

\author{
Imen Ben Amor ${ }^{1}$ \\ ${ }^{1}$ Paris Dauphine University, Paris, France \\ Correspondence: Imen Ben Amor, Paris Dauphine University, Paris, France. E-mail: imenbenamor@yahoo.fr
}

Received: April 26, 2015

Accepted: March 1, 2016 Online Published: March 25, 2016

doi:10.5539/ijms.v8n2p38

URL: http://dx.doi.org/10.5539/ijms.v8n2p38

\begin{abstract}
Nowadays, pricing is one of the most challenging tasks for marketers. Despite its importance for both academics and practitioners, consumers' reactions to prices remain not clear, especially with the emergence of new forms of prices, among which we can highlight the use of complex prices, which is becoming increasingly popular. Complex prices' perception is highly dependent on the way they are communicated; consequently, complex prices communication plays a crucial role in shaping perception. This study is a continuity of previous researches that have validated the perceptual effects of complex prices communication. It attempts to show the effects complex prices communication has on its perceived fairness. In addition, the effects of the moderating variables; Seller Credibility and Responsibility Attribution (i.e., inferred motive) are studied. One hundred thirty-five undergraduate students participated in the study. They were randomly assigned to 2 (sequential communication of complex price vs non sequential communication of complex price) $\mathrm{x} 2$ (credible seller vs less credible seller) conditions. Manipulation consisted of presenting a scenario of buying an online air ticket. The results of our research highlight that sequential complex price communication has a significant effect on its perceived fairness. In particular, the results show that the perceived fairness of price is more negatively affected when the seller lacks credibility according to consumers. Also, it has been proved that the delayed communication of some of the complex price components could be perceived as a way to get a higher profit, which deepens the negative perceived fairness.
\end{abstract}

Keywords: complex price, perceived fairness, seller credibility, inferred motive

\section{Introduction}

Nowadays, pricing is one of the most challenging tasks for marketers. Despite its importance for both academics and practitioners, consumers' reactions to prices remain not clear, especially with the emergence of new forms of prices, among which we can highlight the use of complex prices, which is becoming increasingly popular. Actually, it has been noticed that we don't not only find this form of prices in traditional shops, mail orders or Internet, but also in places where it is least expected taking new forms and shapes. For example, we can find it in hotels once we want to pay keys supplement, or in stores where we want to buy Christmas tree installation, etc. (Bertini \& Wathieu, 2004).

\subsection{Complex Prices: Definition}

A complex price could be defined as any price which is composed of, at least, two components. In other words, when we have a complex price, the consumer is required to carry on arithmetic operations in order to establish the final price.

\section{Different forms that may be used:}

1) The final price consists of a basic price that should be multiplied by a number of months (Estelami, 1997). For instance, the monthly subscription tariff of a telecommunication package consists of the monthly fee multiplied by the number of months depending on the contract duration (ranging from 12 to 24 months).

2) The total price is composed of the main price to which some surcharges may be added (Morwitz et al., 1998). These surcharges (which are called extra-component) are usually of a less amount when compared to the main price. A good example to this form is shipping charges or insurance fees. In the marketing literature, this form of price is usually called "partitioned". 
3) The promotional price displayed during the sales period indicated without mentioning the final price (e.g., \% 49.99 reduction or $25 \%$ off) (Kim \& Kramer 2006).

The literature addressing this filed is relatively recent and it is mainly concerned with products. Yet, the results of the aforementioned studies encouraged sellers to apply this relatively new form of prices in order to attract consumers by hiding some of the price components. Actually, the reason behind this employment is related to the effectiveness of this form of communication in reducing the perceived sacrifice, and this is for two reasons: (1) the consumer tends to use heuristic approach to get the final price or (2) he completely neglects the extracomponent. However, few prospective studies have warned about the negative effects related to this form of communication, since the consumer could feel that he was deceived by the company (Lee \& Hann 2002; Romani 2006, Carlson \& Weathers 2008).

Actually, Complex prices perception is highly dependent on the way they are communicated. Consequently, this research aims at studying one component of the complex price communication which is sequentiality (Note 1). The study will examine its effect on the perceived price fairness by assuming that the difference between the estimated price and the actual one is created by the delayed communication of some of the price components, which may negatively affect its fairness since this former is partially determined by the perceived profits of the seller. This difference, indeed, may be considered as a technique for obtaining an additional profit (Martin-Ruiz \& Rondan-Cataluna, 2008).

This study is a continuity of past research that has validated the perceptual effects of complex prices communication. It attempts to show the effects of complex prices communication on its perceived fairness. Also, the effect of the moderating variables Seller Credibility and Attribution of Responsibility (i.e., inferred motive) are studied. A $2 \times 2$ between-subjects design was established in order to test the effect of these variables. In the following part, both conceptual and hypothetical frameworks are presented. Then, results and discussion are exposed. Finally, we discuss the limitations of this study in addition to some suggestions for future research.

\subsection{Conceptual Framework and Hypotheses}

\subsubsection{Sequential Price Communication and Perceived Fairness}

Complex price sequential communication refers to the delayed presentation of charges associated to the product/service price. We assume that the sequential communication of the different components of the complex price reduces its perceived fairness and this is for two reasons. Firstly, the progressive communication of the information related to the price usually requires a longer and a sustained effort from the consumer especially that the incurred cost increases. The sequential communication of charges relatively modifies between the buyer's contributions/retributions ratio, leading to a lower perceived fairness (Huppertz et al., 1978).

Secondly, the consumer, who wants to be aware of all the elements associated to the transaction, can perceive this delayed communication of the shipping charges as a deliberate manipulative intent (Campbell, 1995). Also, it can be seen as an asymmetry of information in the seller's favor. In fact, the consumer may perceive the communication of a lower price (due to the non-integration of all its components) as an attempt to attract him in order to be stuck in the buying process. As a result, the consumer can accuse the company of deceiving him, and this can negatively affect on the company's image by harming its reputation or by generating a lack of trust ect. (Romani, 2006). Accordingly, we propose to test the following hypothesis:

\section{H1: The sequential communication of a complex price has a negative effect on its perceived fairness.}

\subsubsection{Complex Price Communication and Perceived Fairness: The Role of Attribution}

The theory of attribution (Weiner 1985) provides a solid base for understanding the mechanism of thinking of an individual encountered in an ambiguous situation. The consumer feels that there is a manipulative intent when he perceives an imbalance between the benefits and the costs proposed by the seller (Campbell, 1995). The perceived cost of the product plays a major role in judging price fairness (Bearden, Carlson, \& Hardesty 2003; Thaler 1983) especially when we take into consideration its perceived legitimacy (Hunt, Kernanand Mizerski, 1983; Weiner 2000; Vaidyanathan \& Aggraw, 2003; Bolton, Warlop, \& Alba, 2003). When cost is perceived as controlled by the seller (e.g., personnel costs), it is likely to be considered less legitimate than other factors which are beyond his control (e.g., inflation, energy or logistics costs). This is referred to as the "Inferred Motive" by Campbell (Campbell, 1999). Thus, as indicated earlier, when the consumer deals with a sequential communication of the various components of a complex price, he can infer the difference as a manipulative intent aiming at maximizing profit (Campbell, 1999). Hence, we propose to test the following hypothesis:

H2: when a complex price is sequentially communicated, the negative effect on the perceived fairness of the price will be more important if the Inferred Motive is attributed to the company. 


\subsubsection{The Moderating Effect of Seller Credibility}

Source Credibility has proved that it influences persuasion (Harmon \& Coney, 1982; Moore, Hausknecht, \& Thamodaran, 1988; Sternthal et al., 1978; Wu \& Shaffer, 1987) and plays a moderating role in the relation between dissatisfaction and attitude change (Aronson, Tuner, \& Carlsmith, 1963; Bergin, 1962; Bochner \& Insko, 1966; Goldberg \& Hartwick, 1990). Other studies proved that Source Credibility effects on how consumers perceive the seller's signals (Sternthal, Dholakia \& Leavitt, 1978; Swartz, 1984). Both the Cognitive Response Model (Greenwald, 1968) and the Elaboration Likelihood Model (Petty \& Caccioppo, 1981) consider Source Credibility as a key-variable in predicting consumers' responses. Consequently, in our research, we propose to examine the effect of the moderating variable Source Credibility on the relation between price communication and perceived fairness:

H3: The sequential communication of a complex price has a lower (higher) effect on perceived price fairness when the seller has a higher (lower) credibility

Figure 1 illustrates our research hypotheses:

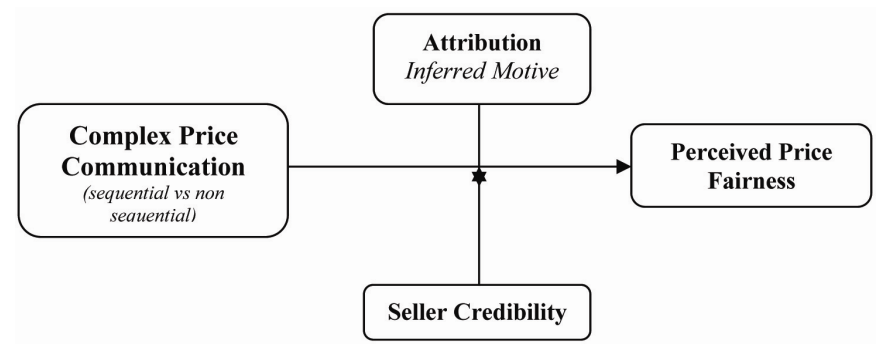

Figure 1. Conceptual model

\section{Method}

One hundred twenty-nine undergraduate students ( $47 \%$ male) participated in our study. They were randomly assigned to 2 (sequential communication of the complex price vs non sequential communication of the complex price) x2 (credible seller vs less credible seller) conditions. Manipulation consisted of presenting a scenario of buying an online air ticket. This industry was chosen due to its frequent use of complex prices.

\section{Manipulated Variables}

The first dimension of the experimental design, which is complex price sequential communication, was created for two stimuli for a Paris-Egypt air ticket: the non-sequential communication price was: 300 Euros including taxes and charges (stimulus 1), and the sequential communication price was: 235 Euros (stimulus 2). The initial price which was found in the internet was 235, and then a 65 Euros were added to the payment at the end of the process. Seller Credibility was employed as follows: it was indicated to the participants that according to "UFC-Que Choisir" (a well-known and credible consumers association in France) company A is offering the best value in the market place. In addition, it has been put in consumers' forums that company A is offering satisfactory services. As for company B, it was indicated that the participants are dealing with a brand new company. Plus, no feedback about company B services was provided.

\section{Results}

\subsection{Manipulation Checks}

Responses were obtained through five-point Likert scale. We selected SPSS to test the proposed hypotheses. The measurement scales can be considered as valid. The three items of the perceived prices fairness (Campbell, 2007) have a satisfactory Cronbach Alpha (0.857). On the one hand, the scale of Seller Credibility has three items and its quality is more than acceptable (alpha 0.89). On the other hand, the Inferred Motive has two items and its quality can be considered as fairly satisfactory $(0.73)$. Both variables employed in the experiment correspond to differences in perception. In particular, as indicated by Boulding \& Kirmani (1993) and Campbell (1999), the manipulation of Seller Credibility is highly effective $(-0.58$ against $0.54, \mathrm{t}=7.83$ significant at $\mathrm{p}<.000)$.

\subsection{The Effect of Complex Price Sequential Communication on Its Perceived Fairness (Principal Effect)}

The results indicate that the sequential communication of complex price significantly influences its perceived 
fairness. Indeed, the $t$ test value was $-6.80(\mathrm{p}<000)$ (Table 1). On one hand, the results show that the perceived fairness of the complex price was significantly low when the price was communicated sequentially (taxes added at the end of the payment process). On the other hand, when the total price was communicated directly the perceived fairness marked a higher rate (Table 2). Thus, $\mathrm{H} 1$ is validated by our results.

Indeed, the gap between the first displayed price and the final one disturbs the equilibrium between seller and buyer ratios (i.e., ratio $=$ retributions/contributions). This confirms the results found by Campbell (1999) and Romani (2006) regarding the effect the seller manipulative intent has on the price perception.

Table 1. Independent samples test

\begin{tabular}{|c|c|c|c|c|c|c|c|c|c|}
\hline & \multicolumn{2}{|c|}{$\begin{array}{l}\text { Levene's Test for } \\
\text { Equality of Variances }\end{array}$} & \multicolumn{7}{|c|}{ t-test for Equality of Means } \\
\hline & \multirow[t]{2}{*}{$\mathrm{F}$} & \multirow[t]{2}{*}{ Significance } & \multirow{2}{*}{$\mathrm{T}$} & \multirow{2}{*}{$\begin{array}{l}\text { Degrees of } \\
\text { freedom }\end{array}$} & \multirow{2}{*}{$\begin{array}{l}\text { Significance } \\
\text { (2-tailed) }\end{array}$} & \multirow{2}{*}{$\begin{array}{l}\text { Mean } \\
\text { Difference }\end{array}$} & \multirow{2}{*}{$\begin{array}{l}\text { Std. Error } \\
\text { Difference }\end{array}$} & \multicolumn{2}{|c|}{$\begin{array}{l}95 \% \text { Confidence Interval } \\
\text { of the Difference }\end{array}$} \\
\hline & & & & & & & & Lower & Upper \\
\hline $\begin{array}{l}\text { Equal } \\
\text { variances }\end{array}$ & 1.413 & 0.237 & -6.80 & 127 & 0.000 & -1.03156 & 0.15154 & -1.3314 & -0.7316 \\
\hline assumed & & & & & & & & & \\
\hline $\begin{array}{l}\text { Equal } \\
\text { variances not } \\
\text { assumed }\end{array}$ & & & -6.86 & 126.661 & 0.000 & -1.03156 & 0.15022 & -1.3288 & -0.7342 \\
\hline
\end{tabular}

Table 2. Group statistics

\begin{tabular}{lllll}
\hline Price communication groups & $\mathrm{N}$ & Mean & Standard deviation & Standard error mean \\
\hline Sequential & 68 & -0.4877 & 0.9215 & 0.1117 \\
Non sequential & 61 & 0.5437 & 0.7840 & 0.1003 \\
\hline
\end{tabular}

\subsection{The Moderating Effect of the Inferred Motive}

The $t$ test $(\mathrm{t}=-7.79, \mathrm{p}<000)$ showed that the effect of the sequential communication of complex price is higher when there is a negative Inferred Motive towards the company. (-1.05 against 0.22 ) (Tables 3 and 4). Thus, H2 is validated.

This result confirms the findings of Campbell (1999) on the effect of Inferred Motive on price perceived fairness. In other words, if the consumer feels that the seller is trying to get more profit through a sequential communication of some of the price components (Inferred Motive), its fairness will be highly negatively affected. This result supports the findings of Martin-Ruiz \& Rondan-Cataluna (2008) which confirm that the seller profits determine price (un) fairness significantly.

Table 3. Independent sample tests

\begin{tabular}{|c|c|c|c|c|c|c|c|c|c|}
\hline & \multicolumn{2}{|c|}{$\begin{array}{l}\text { Levene's Test for } \\
\text { Equality of Variances }\end{array}$} & \multicolumn{7}{|c|}{ t-test for Equality of Means } \\
\hline & \multirow[t]{2}{*}{$\mathrm{F}$} & \multirow[t]{2}{*}{ Significance } & \multirow[t]{2}{*}{$\mathrm{T}$} & \multirow{2}{*}{$\begin{array}{l}\text { Degrees of } \\
\text { freedom }\end{array}$} & \multirow{2}{*}{$\begin{array}{l}\text { Significance } \\
\text { (2-tailed) }\end{array}$} & \multirow{2}{*}{$\begin{array}{l}\text { Mean } \\
\text { Difference }\end{array}$} & \multirow{2}{*}{$\begin{array}{l}\text { Std. Error } \\
\text { Difference }\end{array}$} & \multicolumn{2}{|c|}{$\begin{array}{l}95 \% \text { Confidence Interval of } \\
\text { the Difference }\end{array}$} \\
\hline & & & & & & & & Lower & Upper \\
\hline $\begin{array}{l}\text { Equal variances } \\
\text { assumed }\end{array}$ & 1.549 & 0.218 & -7.791 & 66 & 0.000 & -1.27513 & 0.16366 & -1.6019 & -0.9483 \\
\hline $\begin{array}{l}\text { Equal variances } \\
\text { not assumed }\end{array}$ & & & -8.058 & 65.841 & 0.000 & -1.27513 & 0.15824 & -1.5911 & -0.9591 \\
\hline
\end{tabular}


Table 4. Group statistics

\begin{tabular}{lllll}
\hline Inferred motive* & $\mathrm{N}$ & Mean & Standard deviation & Standard error mean \\
\hline Yes & $38^{* *}$ & -0.4877 & 0.9215 & 0.1117 \\
No & $30^{* *}$ & 0.5437 & 0.7840 & 0.1003 \\
\hline
\end{tabular}

Note. *Inferred motive, originally interval variable, was median-splitted and transformed into a dummy variable. Two sub-groups were created: a group which perceived an inferred motive within the sequential communication of the complex price and a group which didn't perceive any inferred motive. ${ }^{* *}$ Only respondents within the sequential communication situation were asked about their perception of an inferred motive (68 respondants).

\subsection{The Moderating Effect of Seller Credibility}

ANOVA indicates that the perceived fairness among the experimental groups is different $(\mathrm{F}=55.3 ; \mathrm{p}<.000)$ (Table 5). The Dunnet's $C$ indicates that the group which has the least Seller Credibility is significantly different than group which enjoys higher credibility when it comes to the sequential communication of complex price (Tables 6 and 7). As a result, Seller Credibility significantly moderates the effect of the sequential communication of complex price on its perceived fairness. Consequently, $\mathrm{H} 3$ is confirmed by these results.

As Bolton et al. (2003) said Seller Credibility could trigger inferences of costs (instead of profits) within consumers. Also, results show that when a credible seller communicates the complex price sequentially, perceived fairness is lower than the control situation (i.e., non sequential communication and credible seller), and even lower than the less credible seller (i.e., non sequential communication and less credible seller). This suggests that Seller Credibility doesn't balance completely the negative effect of sequential communication on perceived fairness.

Table 5. ANOVA

\begin{tabular}{llllll}
\hline & Sum of squares & Degrees of freedom & Mean Square & F & Significance \\
\hline Between groups & 73.006 & 3 & 24.335 & 55.313 \\
Within groups & 54.994 & 125 & 0.440 & \\
Total & 128.000 & 128 & & \\
\hline
\end{tabular}

Table 6. Descriptives: dependant variable: perceived price fairness

\begin{tabular}{|c|c|c|c|c|c|c|c|c|}
\hline & \multirow[t]{2}{*}{$\mathrm{N}$} & \multirow[t]{2}{*}{ Mean } & \multirow{2}{*}{$\begin{array}{l}\text { Standard } \\
\text { deviation }\end{array}$} & \multirow[t]{2}{*}{ Standard error } & \multicolumn{2}{|c|}{$95 \%$ confidence interval for mean } & \multirow[t]{2}{*}{ Minimum } & \multirow[t]{2}{*}{ Maximum } \\
\hline & & & & & Lower bound & Upper bound & & \\
\hline $\begin{array}{l}\text { Credible } \\
\text { sequential }\end{array}$ & 36 & 0.2220 & 0.4890 & 0.8151 & 0.0565 & 0.3875 & -0.5172 & 1.2462 \\
\hline $\begin{array}{l}\text { Credible non } \\
\text { sequential }\end{array}$ & 31 & 0.6053 & 0.7695 & 0.1382 & 0.3230 & 0.8876 & -0.8205 & 1.8529 \\
\hline $\begin{array}{l}\text { Less credible } \\
\text { sequential }\end{array}$ & 32 & -1.2864 & 0.5672 & 0.1002 & -1.4909 & -1.0818 & -2.1161 & -0.7445 \\
\hline $\begin{array}{l}\text { Less credible non } \\
\text { sequential }\end{array}$ & 30 & 0.4801 & 0.8068 & 0.1473 & 0.1788 & 0.7814 & -1.4272 & 1.8529 \\
\hline Total & 129 & 0.0000 & 1.0000 & 0.0880 & -0.1742 & 0.1742 & -2.1161 & 1.8529 \\
\hline
\end{tabular}

Table 7. Multiple comparisons: dependant variable: perceived price fairness (Dunnett's C)

\begin{tabular}{lll}
\hline Price presentation $(\mathrm{I})$ & Price presentation $(\mathrm{J})$ & Mean difference (I-J) \\
\hline Credible and sequential & Credible non sequential & $-0.3832681^{*}$ \\
& Less credible sequential & $1.5084826^{*}$ \\
& Less credible non sequential & $-0.2580503^{*}$ \\
Credible non sequential & Credible sequential & $0.3832681^{*}$ \\
& Less credible sequential & $1.8917507^{*}$ \\
Less credible sequential & Less credible non sequential & $0.1252178^{*}$ \\
& Credible sequential & $-1.5084826^{*}$ \\
Less credible non sequential & Credible non sequential & $-1.8917507^{*}$ \\
& Less credible non sequential & $-1.7665329^{*}$ \\
& Credible sequential & $0.2580503^{*}$ \\
& Credible non sequential & $-0.1252178^{*}$ \\
\hline
\end{tabular}

Note. *The mean difference is significant at 0.05 level. 


\section{Discussion}

The sequential communication of a complex price refers to the delayed communication of some of its. The consumer who aspires to know all the elements associated with the transaction may perceive that as a deliberate manipulative intent to deceive him (Campbell, 1995).The results of the present research highlight the existence of such an effect. In particular, it has been proved that the perceived fairness of price is more negatively affected when the seller lacks credibility according to consumers. In addition, it has been proved that Credible Seller should not "count" entirely on the "benefit of doubt" (Campbell, 1999) given by the consumer and should not take the risk of communicating a complex price in a misleading and manipulative manner.

Indeed, it has been shown that when the consumer conceives the delayed communication of some of the complex price components as a way to get a higher profit, the perceived fairness will be highly negatively affected. It would be significantly regarded if future researches would examine the effect of interaction between the Seller Credibility and the Inferred Motive in complex price communication in more in-depth.

Also, it would be useful to test the effect of the moderating variables which are related to individuals, such as skepticism toward marketing practices. In the literature, Skepticism is defined as a stable personal trait that characterizes people who have a spontaneous tendency to doubt the veracity of the various forms of marketing communication (Obermiller \& Spangenberg, 1998; Schindler et al., 2005). It could address marketers' motivations, advertising arguments, and actions related to Public Relations. One can assume that skeptical consumers, when compared to others, perceive greater unfairness. Thus, skepticism could play a moderating role by intensifying the negative relationship between complex price communication and its perceived fairness.

Besides, the present research considered only students' perceptions. This segment of consumers may be more sensitive to price than other segments, which could accentuate negative perception of fairness. Unfortunately, this experiment design limits the external validity of the results. It would be interesting that future research examine perception of complex prices within different segments, such as managers or seniors.

Finally, it should be highlighted that only one form of complex price communication has been investigated in this research (i.e., sequential communication). Therefore, future studies might approach other forms and examine their effects on price perceived fairness, for instance, addressing the number of price components or the visual salience of some components compared to others.

\section{References}

Aronson, E., Turner, J. A., \& Carlsmith, J. M. (1963). Communicator credibility and communication discrepancy as determinants of opinion change. The Journal of Abnormal and Social Psychology, 67(1), 31-36. http://dx.doi.org/10.1037/h0045513

Bearden, W., Carlson, J. P., \& et Hardesty, D. M. (2003). Using invoice price information to frame advertised prices. Journal of Business Research, 56(5), 355-366. http://dx.doi.org/10.1016/S0148-2963(01)00225-9

Bergin, A. E. (March-December 1962). The Effect of Dissonant Persuasive Communications upon Changes in $\begin{array}{lllll}\text { Self-Referring Attitudes. Journal of } & \text { Personality, } & 30, & \text { 423-438. }\end{array}$ http://dx.doi.org/10.1111/j.1467-6494.1962.tb02314.x

Bertini, M., \& Wathieu, L. (2004). Price Format and Evaluation of Multicomponent Goods. Working Paper-Harvard Business School Division of Research.

Bochner, S., \& Insko, Ch. A. (December 1966). Communicator Discrepancy, Source Credibility, and Opinion Change. Journal of Personality and Social Psychology, 4, 614-621. http://dx.doi.org/10.1037/h0045513

Bolton, L. E., Warlop, L., \& et Alba, J. W. (2003). Consumer perceptions of price (un) fairness. Journal of Consumer Research, 29(4), 474-491. http://dx.doi.org/10.1086/346244

Boulding, W., \& Kirmani, A. (1993). A consumer-side experimental examination of signaling theory: do consumers perceive warranties as signals of quality? Journal of Consumer Research, 6(1), 111-123. http://dx.doi.org/10.1086/209337

Campbell, M. C. (1995). When attention-getting tactics elicit consumer inferences of manipulative intent: the importance of balancing benefits and investments. Journal of Consumer Psychology, 4(3), 225-254. http://dx.doi.org/10.1207/s15327663jcp0403_02

Campbell, M. C. (1999). Why did you do that? The important role of inferred motive in perceptions of price fairness. Journal of Product and Brand Management, 8(2), 145-152. http://dx.doi.org/10.1108/10610429910266995 
Campbell, M. C. (2007). Says Who?! How the Source of Price Information and Affect Influence Perceived Price (Un) fairness. Journal of Marketing Research, 44(2), 261-271. http://dx.doi.org/10.1509/jmkr.44.2.261

Carlson, J. P., \& Weathers, D. (2008). Examining differences in consumer reactions to partitioned prices with a variable number of price components. Journal of Business Research, 61(7). http://dx.doi.org/10.1016/j.jbusres.2007.09.005

Estelami, H. (1997). Consumer perceptions of multi-dimensional prices. In M. Brucks \& D. J. MacInnis (Eds), Advances in Consumer Research (vol. 24, pp. 392-399). Association for Consumer Research, Provo, UT. http://dx.doi.org/10.1108/eb027697

Goldberg, M. E., \& Hartwick, J. (September 1990). The Effects of Advertiser Reputation and Extremity of Advertising Claim on Advertising Effectiveness. Journal of Consumer Research, 17, 172-179. http://dx.doi.org/10.1086/208547

Greenwald, A. G. (1968). Cognitive learning, cognitive response to persuasion and attitude change. In A. Greenwald, T. Brock, \& T. Ostrams (Eds.), Psychological foundations of attitudes (pp. 147-170). New York: Academic. http://dx.doi.org/10.1016/B978-1-4832-3071-9.50012-X

Harmon, R. R., \& Coney, K. A., (1982). The Persuasive Effects of Source Credibility in Buy and Lease Situations. Journal of Marketing Research, 19(May), 255-260. http://dx.doi.org/10.2307/3151625

Hunt, M. J., Kernan, J. B., \& et Mizerski, R. W. (1983). Causal inference in consumer response to inequitable exchange: a case of deceptive advertising. Advances in Consumer Research, 10(1), 136-141.

Huppertz, J. W., Arenson, S. J., \& Evans, R. H. (1978). An Application of Equity Theory to Buyer-Seller Exchange Situations. Journal of Marketing Research, 15(May), 250-260. http://dx.doi.org/10.2307/3151255

Kim, H., \& Kramer, T. (2006). Pay $80 \%$ " versus "get $20 \%$ off: The effect of novel discount presentation on consumers” deal perceptions. Marketing Letters, 17(4). http://dx.doi.org/10.1007/s11002-006-9309-7

Lee, Y. H., \& et Han, C. Y. (2002). Partitioned pricing in advertising : Effects on brand and retailer attitudes. Marketing Letters, 13(1), 27-40. http://dx.doi.org/10.1023/A:1015011108224

Martin-Ruiz, D., \& Rondan-Cataluna, F. J. (2008). The nature and consequences of price unfairness in services: A comparison to tangible goods. International Journal of Service Industry Management, 19(3), 325-352. http://dx.doi.org/10.1108/09564230810875002

Moore, D., Hausknecht, D., \& Thamodaran, K. (1988). Time compression, response opportunity and persuasion. Journal of Consumer Research, 13(1), 12-24.

Morwitz, V. G., Greenleaf, E. A., \& Johnson, E. J. (1998). Divide and prosper: consumers' reactions to partitioned prices. Journal of Marketing Research, 35(4), 453-463. http://dx.doi.org/10.2307/3152164

Obermiller, C., \& Spangenberg, E. R. (1998). Development of a Scale to Measure Consumer Skepticism toward $\begin{array}{lllll}\text { Advertising. Journal of } & \text { Consumer } & \text { Psychology, } & 7(2), & 159-187 .\end{array}$ http://dx.doi.org/10.1207/s15327663jcp0702_03

Petty, R. E., \& Cacioppo, J. (1979). Issue-involvement can increase or decrease persuasion by enhancing message relevant cognitive responses. Journal of Personality and Social Psychology, 37, 1915-1926. http://dx.doi.org/10.1037/0022-3514.37.10.1915

Romani, S. (2006). Price misleading advertising: effects on trustworthiness toward the source of information and willingness to buy. Journal of Product and Brand Management, 15(2), 130-138. http://dx.doi.org/10.1108/10610420610658965

Schindler, R., Morrin, M., \& et Bechwati, N. (2005). Shipping charges and shipping charges skepticism: implications to direct marketers. Journal of Interactive Marketing, 19(1), 41-52. http://dx.doi.org/10.1002/dir.20030

Sterthal, B., Dholakia, R. R., \& Leavitt, C. (1978). The Persuasive Effect of Source Credibility: Tests of Cognitive Response. Journal of Consumer Research, 4(March), 252-260. http://dx.doi.org/10.1086/208704

Swartz, T. A. (1984). Relationship between source expertise and source similarity in an advertising context. Journal of Advertising, 13, 49-54. http://dx.doi.org/10.1080/00913367.1984.10672887

Thaler, R. (1983). Transaction Utility Theory. In R. P. Bagozzi, \& A. M. Tybout (Eds.), Advances in Consumer Research, 10, 229-232. Ann Arbor, MI: Association for Consumer Research.

Thaler, R. (1985). Mental accounting and consumer choice. Marketing Science, 4, 199-214. 
http://dx.doi.org/10.1287/mksc.4.3.199

Vaidyanathan, R., \& et Aggarwal, P. (2003). Who is the fairest of them all? An attributional approach to price fairness perceptions. Journal of Business Research, 56(6), 453-463. http://dx.doi.org/10.1016/S0148-2963(01)00231-4

Weiner, B. (1985). An Attributional theory of achievement motivation and emotion. Psychological Review, 106(2). http://dx.doi.org/10.1037/0033-295X.92.4.548

Weiner, B. (2000). Attributional thoughts about consumer behaviour. Journal of Consumer Research, 27(3), 382-387. http://dx.doi.org/10.1086/317592

Wu, C., \& Shaffer, D. (1987). Susceptibility to Persuasive Appeals as a Function of Source Credibility and Prior Experience with the Attitude Object. Journal of Personality and Social Psychology, 52(April), 677-688. http://dx.doi.org/10.1037/0022-3514.52.4.677

\section{Note}

Note 1. Delayed presentation of charges associated with the price of the product/service.

\section{Copyrights}

Copyright for this article is retained by the author, with first publication rights granted to the journal.

This is an open-access article distributed under the terms and conditions of the Creative Commons Attribution license (http://creativecommons.org/licenses/by/3.0/) 